

Internationalized Framing in Social Movements against Mining in India and the Philippines

Borde, R., \& Rasch, E. D.

This is a "Post-Print" accepted manuscript, which has been published in "J ournal of Developing Societies"

This version is distributed under a non-commercial no derivatives Creative Commons (c) (1) @ @ (CC-BY-NC-ND) user license, which permits use, distribution, and reproduction in any medium, provided the original work is properly cited and not used for commercial purposes. Further, the restriction applies that if you remix, transform, or build upon the material, you may not distribute the modified material.

Please cite this publication as follows:

Borde, R., \& Rasch, E. D. (2018). Internationalized Framing in Social Movements against Mining in India and the Philippines. Journal of Developing Societies, 34(2), 195-218. DOI: 10.1177/0169796X18767504

You can download the published version at:

https://doi.org/10.1177/0169796X18767504 


\title{
Internationalized Framing in Social Movements against Mining in India and the Philippines
}

- $\quad$ Radhika Borde and Elisabet Dueholm Rasch

\begin{abstract}
:
There are several documented cases of indigenous peoples' conflicts with mining companies, often for the reason that the land planned for mining is sacred or culturally significant to them. This paper presents a comparative analysis of two specific anti-mining social movements in India and the Philippines that combined an emphasis on environmental protection with an emphasis on indigenous cultural rights. We show how the emphasis on indigeneity in these social movements played itself out in relation to globalized frames, as well as the other frames within which the movements were also situated.
\end{abstract}

Keywords: Indigenous Peoples, Social Movements, Framing, India, Philippines, Mining

\section{Introduction:}

In this paper we present a comparative study of how social movements against mining in India and the Philippines use globalized discourses and resources, as well as help from international actors to champion the cause of indigenous land that has cultural or sacred value. The Indian social movement that we study aimed at protecting the Niyamgiri Mountain in India from mining and the Philippine social movement aimed at preventing mining on the southern part of the Philippine island Palawan. We believe that this comparative study of social movements against mining on indigenous land in these two democratic Asian polities with emerging economies, yields valuable insights since both have minority populations of indigenous peoples, but each of 
these contexts differs in its localized understanding of indigeneity and associated issues (Li, 2010; Kingsbury, 1998). This study examines how these social movements in India and the Philippines emphasized indigenous issues in the context of globalization, and it resonates with the argument that indigenous ecological identities cannot be studied in isolation from the internationalized dynamics that shape them (Radcliffe, 2014).

The increasing importance given to indigenous peoples in discussions related to environmental conservation has been noted by scholars (Hames, 2007; Dove, 2006) and is visible in global environmental policy-making. For example, the World Bank refers to indigenous peoples as partners in biodiversity conservation (Sobrevila: 2008) and the United Nations Convention on Biological Diversity includes provisions that relate indigenous peoples to nature conservation policy (Reimerson, 2013). We call this globalized linkage between indigenous peoples and nature conservation 'the globalized frame of the valorization of indigeneity'. It has been argued that the globalized frame of the valorization of indigeneity is the result of indigenous peoples’ successful deployment of a "politics of morality” (Muehlebach, 2001: 425) against the ecological failures of modern civilization globally, as well as a political rhetoric that attempts to answer Western quests for native or aboriginal wisdom (Pieck, 2006). Conversely, it has also been argued that the globalized frame of the valorization of indigeneity constructs an essentialized indigenous identity, which indigenous peoples need to embrace in order to possess environmental agency (Lindroth and Sinevaara-Niskanen, 2013). Indigenous sacred/culturally valued lands are singled out for special protection globally. For example, the United Nations Convention on Biological Diversity has developed a set of (voluntary) guidelines on the protection of indigenous sacred natural sites. These are called the Akwé: Kon Guidelines and are defined as "voluntary guidelines for the conduct of cultural, environmental and social 
impact assessments regarding developments proposed to take place on, or which are likely to impact on, sacred sites and on lands and waters traditionally occupied or used by indigenous and local communities” (CBD, 2004). The Akwé: Kon Guidelines are argued to have been formulated with site-specific biodiversity conservation in mind, after it became established that there was a link between cultural and biological diversity and that they should be conserved in tandem (Djoghlaf, 2012). However, the Akwé: Kon Guidelines are also an example of a nonbinding policy instrument that grants cultural rights to indigenous peoples. The globalized valorization of indigeneity is an example of a rights discourse that radically reconfigures that position of the rights' recipient. Within the framing of the globalized valorization of indigeneity, indigenous peoples are understood to be experts in relation to conservation and they are also (and in light of this) granted special rights to conserve their lands and territories that possess cultural or spiritual value for them. In many ways, the globalized frame of the valorization of indigeneity reflects the ethical stance vis-a-vis the marginalized/subaltern 'other' which postcolonial scholar Gayatri Spivak prescribes (see Vinayaraj, 2016; Kapoor, 2004) i.e. a stance that facilitates a mutual and respectful exchange.

The central question of this study is how social movements aimed at defending 'places' (see Dirlik, 1999) achieve a discursive fit with the globalized frame of the valorization of indigeneity. To answer it we have developed the concept of frame internationalization, inspired by Tarrow's conceptualization of internalization (Tarrow, 2010a) and the concept of frame bridging (Snow et al., 1986). Tarrow's conceptualization of internalization relates to the ways domestic or local movements include globalized discourses into their framing (Tarrow, 2010a) and frame-bridging describes how social movements can connect an issue they champion with another issue (Snow et al., 1986). 
We study the entanglements between local and global frames and also emphasize the role of the actors who construct and operationalize the frames we study. This study contributes to scholarship on social movements in which the translation of globalized frames to the local scale is emphasized (Merry, 2006). Our contribution can be divided into three areas. Firstly, we unpack the framing process that is involved in making a locally and domestically situated social movement align with globalized agendas while simultaneously ensuring that it retains its appeal for its local and domestic constituencies by continuing to address issues that are of relevance in those contexts. Secondly, we emphasize the pro-active aspect of the framing process which we unpack - we argue that social movements aimed at defending place actively engage with globalization in order to strengthen themselves discursively. This demonstrates that these social movements are not "place-bound" (Dirlik, 1999: 154) and that the defence of place does not necessarily need to occur in opposition to globalization (see Escobar, 2001). Our third contribution is more methodological: we show that frames are dynamic and should be studied as processes rather than as static frames - this is a point that has been mentioned in methodological discussions related to frame analysis (Johnston, 2002), and is consequently one that we support and add to.

\section{Theoretical Framework:}

To analyse the ways in which social movements mobilize resistance towards mining on indigenous land through a place-based (re)construction of the globalized frame of the valorization of indigeneity, we developed the concept of 'frame internationalization', drawing on insights from framing theory (Benford and Snow 2000) and Tarrow's conceptualization of internalization (Tarrow, 2010a), and building upon the work of scholars who have studied local- 
global interactions in the context of globalization (Tarrow 2010a; Levitt and Merry 2009; Swyngedouw 2004; Escobar 2001)

A frame is defined by scholars as "an interpretative schemata that simplifies and condenses the 'world out there”' (Snow and Benford, 1992: 137). Following Goffman’s study of how frames facilitate a particular interpretation of social reality (Goffman, 1974), social movements' scholars have engaged with the concept in their studies on mobilization dynamics (Benford, 1997). In this regard they have focused on 'collective action frames', which are defined as emergent action-oriented sets of beliefs inspiring meaning and legitimizing social movement activities and campaigns (Snow and Benford, 1992: 137). Framing occurs through language, and is based upon discourse which is defined as a collective and contested process of meaning production (Steinberg, 1998).

In their review of scholarship on social movements and framing, Benford and Snow have discussed the attention given to strategic framing processes associated with social movements (Benford and Snow, 2000). They define strategic framing processes as "deliberative, utilitarian, and goal directed” (Benford and Snow, 2000: 624) and go on to identify and discuss four such processes: namely, frame bridging, frame amplification, frame extension and frame transformation (Benford and Snow, 2000). Of these, frame-bridging is most relevant to our conceptualization of frame internationalization. Defined as the "linking of two or more ideologically congruent but structurally unconnected frames regarding a particular issue or problem" (Benford and Snow, 2000: 624) frame bridging can be seen in the social movements we study: both the environmental justice frame in the Indian social movement and the ecological frame used by the anti-mining movement on Palawan are linked with aspects of the indigenous cultural rights frame. 
Internalization is conceptualized by Tarrow (2010a) as one of several different mechanisms by which domestic and international inter-contextual coupling may occur in social movements, and how domestic and international politics may intersect to aid the articulations of localized struggles (Tarrow, 2010a). As per Tarrow's emphasis, these mechanisms "bridge domestic and international politics in a sustained way without displacing one or the other or homogenizing the two" (Tarrow, 2010a: 174). The mechanisms are 1) internalization 2) externalization 3) transnationalization 4) insider-outsider coalitions (Tarrow, 2010a: 174-180). Internalization is the discursive process by which struggles absorb global norms or values that relate to their goals (Della Porta and Tarrow, 2005), and then re-frame their agendas as having a universal component, or as participative in global processes (Tarrow, 2010a: 175-176).

Benford and Snow stress the importance of a frame’s "narrative fidelity" or "cultural resonance” (Benford and Snow, 2000: 622). By this they mean that social movements frame themselves in ways that resonate with the "inherent ideology" of their targets (Benford and Snow, 2000: ibid). We argue that the internationalization of framing that was seen in the antimining movements in India and the Philippines did not detract from the movements' commitment to being locally relevant, and that the internationalized framing continued to have cultural resonance with each local context.

We understand frame internationalization to be shaped by processes of globalization, internationalization and glocalization. We refer to the frame of the valorization of indigeneity that social movements in India and the Philippines engage with as being globalized, as it is present at the trans-boundary or meta-state scale (Garcia, 2013), which is the scale at which globalization is situated (Daly, 1999). However, though the globalized frame of the valorization of indigeneity is not bounded within the scales of specific nation-states, the social movements we 
study do engage with this frame from the context of bounded nation-states. It is for this reason that we have chosen to term these engagements with the globalized frame of the valorization of indigeneity 'frame internationalization' rather than 'frame globalization’.

Frame internationalization is thus a composite of processes of frame-bridging and internalization, in which the cultural resonance that internationalized frames may have with local/domestic contexts is important. Frame internationalization can be compared to the discursive process of translating globalized discourses for local contexts that Levitt and Merry have termed vernacularization (2009). However, frame internationalization is a process of including globalized elements in a frame, in such a way that it can address a global as well as a local and national audience. Frame internationalization can be discussed as a glocalization of resistance, and as such it adds to scholarship on glocalization and rescaling (see Swyngedouw, 2004), which however, with its focus on production and networks, leaves a research gap vis-a-vis studies of resistance. Scholars such as Kurtz have also studied the glocalization of resistance (see Kurtz, 2003). However, Kurtz's formulation of scale frames (Kurtz, 2003) implies a different framing dynamic from the one we discuss. Kurtz defines scales frames as the "discursive practices that construct meaningful (and actionable) linkages between the scale at which a social problem is experienced and the scale(s) at which it could be politically addressed or resolved” (Kurtz, 2003: 894) - this is similar to the dynamic that Tarrow refers to as externalization (Tarrow, 2010). However, internationalized framing as theorized by us, relates to articulations that argue for an extension of the scale at which a problem finds relevance (an extension from the local or national scale to the global scale). This is done with the aim to further its political resolution at the scale at which it was originally understood to be experienced - i.e. by showing that a problem is relevant at multiple scales, its importance is underscored. 


\section{Methodology:}

The data that the study presents and analyses was gathered by each co-author using qualitative methodologies and together we have taken a qualitative approach towards frame analysis (Koenig, 2006) as we envisioned a qualitative approach to be most suitable to our aims of conducting a nuanced analysis of local-global linkages in relation to the framing of social movements. For the Indian case study, the data was primarily gathered using interviews, many of which employed oral history interviewing techniques (Thomson, 1998). Fifteen in-depth oral history interviews were conducted for the Indian case study and most were recorded on a digital voice recorder (in a few cases interviewees requested that the interview should not be recorded). Most of the interviews were conducted in Bhawanipatna, which is the district capital of Kalahandi where Niyamgiri is located. A few of the interviews were also conducted in Delhi, where some of the national-scale activists who were supporting the Niyamgiri Movement were based. Participant observation, both in the daily life of an indigenous community and in a protest rally were also undertaken. Fieldwork was conducted for a few months each in 2011, 2012 and 2013.

The fieldwork on Palawan was conducted in November 2011. The author lived in a community and engaged in participant observation in daily life, conducting numerous informal interviews and observations, which were recorded in fieldnotes. The fieldwork included participant observation at several meetings in preparation for a community consultation, and at the consultation itself. Semi-structured interviews were conducted with fifteen activists, community leaders and politicians at Puerto Princesa and Brooke’s Point. The author also participated in activities related to other campaigns in the Philippines, such as an awareness- 
raising campaign about palm-oil extraction and a solidarity meeting in Rome, as a way of getting a better general understanding of the ways local activist groups work. Numerous documents were analysed, including lawsuits, meeting minutes, and policy documents. Additionally, observation was conducted online, by means of an analysis of the use of Facebook by Philippines-based activist groups.

The authors used thematic analysis to analyse their data and took an inductive approach towards it (Ryan and Russel, 2003). The emergent themes that were identified were then compared and discussed and the concept of frame internationalization was developed. The study adopts a paired comparison approach in order to better illustrate the concept of frame internationalization.

Paired comparisons are understood to facilitate analyses aimed at "correcting generalizations from single cases” (Tarrow, 2010b: 245) and in the context of this study it allows the relevance of the concept of frame internationalization to be demonstrated beyond the confines of a single case study. In this study we draw out two country-specific parallel narratives of movements against mining and show how they internationalize their framing practices by engaging with the globalized frame of the valorization of indigeneity after bridging an indigenous cultural rights frame with the frames within which they were previously situated. These narratives are then discussed in a comparative manner. The social movements against mining in India and the Philippines that we study, were seen to have a strong environmental focus, as well as an important agenda to protect indigenous land of cultural value. The similarities and differences in the way these two foci merged and how the movements subsequently internationalized are presented to facilitate a nuanced understanding of frame internationalization processes. Most of the data presented below was derived from interviews, 
but it is important to mention that it is mostly paraphrased, as the data that was collected on the Philippine social movement was recorded in the form of fieldnotes. For the purpose of ensuring consistency across the two parallel narratives - direct quotations are kept to a minimum.

\section{Frame internationalization and the Indian social movement - the indigenous eco- spirituality frame:}

The Indian social movement that is analysed in this study is the social movement to save the Niyamgiri Mountain in the state of Odisha from bauxite extraction by Vedanta Resources, a UKbased mining company that began operating in the region in 1997 (Kumar, 2014). Initially, local, urban and semi-urban residents displaced and/or affected by the construction and operation of the company's refinery led the protests. In 2004, when an agreement was signed between the government of Odisha and Vedanta Resources for the mining of the Niyamgiri Mountain (Sahu, 2008), an (arguably) indigenous or Adivasi community ${ }^{1}$ known as the Dongaria Kondhs, which lived on the Niyamgiri Mountain and worshipped it, entered the protest movement against Vedanta Resources. The Dongaria Kondhs were assisted in entering the movement by the local residents who were already campaigning - and subsequent to their involvement, the movement went on to focus on opposing the company's plan to mine the top of Niyamgiri (Kumar, 2014) which was estimated to contain approximately 75 million tonnes of bauxite (Temper and Martinez-Alier, 2013) and the movement became framed primarily in terms of protecting the Dongaria Kondhs' sacred natural site. The involvement of the Dongaria Kondhs in the Niyamgiri Movement drew in many international supporters. The Indian government banned the mining project on Niyamgiri in 2014. 
The emphasis on indigeneity and associated rights-claims became foregrounded in the Niyamgiri Movement a few years after its onset. As previously mentioned, at its outset, groups displaced by the construction of its refinery who were mostly from non-Adivasi backgrounds, environmentally-minded residents of the towns around it and the Niyamgiri Mountain, spearheaded the struggle. In its early years, the movement was framed in terms of critiquing the model of extractive-sector driven development which the state government of Odisha was championing, in terms of combating the pollution that the aluminium refining process would cause, and also as a struggle to preserve the drought-prone region's rivers from the impact of mining the mountain in which they had their source. The region in which Niyamgiri is located is economically marginalized and in the context of the Niyamgiri Movement residents articulated fears of being further marginalized by a mining project that they saw as burdening them with an unfair share of environmental pollution and degradation without compensatory benefits (interviews, August 2011), i.e. local activists initially framed the Niyamgiri Movement in terms of a struggle for environmental justice (see Schroeder et al., 2008). However, they went on to internationalize the movement and it is seen that the bridging of the environmental justice frame with the indigenous rights frame proved to be useful in this regard.

One of these residents and a student activist stated in an interview: "in this way, since 2002, we were protesting in a small way. But when we saw that the government was intent on stopping the movement, then we thought we must make it an international issue...” (interview with local student activist, August 2011). Local student activists gave a major impetus towards the internationalization of the Niyamgiri Movement when they took their protest against the mining company into the Odisha state legislative assembly and dropped anti-Vedanta leaflets onto parliamentarians from the visitor's gallery. The students' protest in the Odisha state 
legislative assembly was reported in the news and caught the attention of the South Asia Amnesty International representative, who went on to involve Amnesty International in the Niyamgiri Movement. Other international organizations like ActionAid and Survival International also got involved in the movement, subsequent and consequent to the prior involvement of Amnesty International (fieldnotes and interviews, August 2011).

The student activists were among the first to initiate a bridging of the frame of indigenous cultural rights in relation to the Dongaria Kondhs, with the prior framing of the Niyamgiri Movement in terms of environmental justice. An important connection between the Dongaria Kondhs' worship of the Niyamgiri Mountain and the ecological discourses within which the Niyamgiri Movement was earlier situated, was the fact that the Dongarias' religiosity was argued to have conserved the biodiversity of the Niyamgiri Mountain. Almost $90 \%$ of Vedanta Resources' 660-hectare mining lease area was reported to be Sal (Shorea robusta) forest, and this was maintained by a Dongaria Kondh taboo on cutting trees on Niyamgiri's summit (Padel and Das, 2010). Hunting is also not permitted on the summit of the Niyamgiri Mountain, and as a result the mountain contains rare species of flora and fauna (Saxena et al., 2010).

International activism against the company was focused on the cultural losses to the Dongaria Kondhs that Vedanta Resources' mining project on Niyamgiri would cause and the consequences of this for the mountain's biodiversity - it managed to engage the participation of several international film celebrities such as Joanna Lumley and Michael Palin, in support of this discursive trajectory.

Though ActionAid and Survival International were not working together in the context of this particular domestic struggle, together they succeeded in helping the Niyamgiri Movement internalize the globalized frame of the valorization of indigeneity and facilitated an emphasis on 
the aspect of the Dongaria Kondhs' reverence for nature which finds celebration within it. Both these organizations engaged in political representations of the religiosity of the Dongaria Kondhs - each with the help of an important act of symbolic protest.

Survival International highlighted the Dongaria Kondhs' reverence for the Niyamgiri Mountain slated to be mined by Vedanta Resources, by drawing parallels between the Dongarias' situation and that of the mythical and indigenous $\mathrm{Na}$ ' Vi tribe in the Hollywood blockbuster Avatar, which was depicted as similarly worshipping land threatened by resource extraction. Two Survival International activists costumed as the $\mathrm{Na}$ ' $\mathrm{Vi}$, stood outside the venue of the 2010 Annual General Meeting of Vedanta Resources in London, holding placards that read 'Save the real Avatar tribe'. They also appealed to James Cameron, the director of the Hollywood film, requesting his support and asking him to watch a documentary on the Dongarias' plight made by Survival International. They achieved this by putting an advertisement in the Hollywood magazine Variety, which was worded in the following manner:

Avatar is fantasy...and real. The Dongria Kondh tribe in India are struggling to defend their land against a mining company hell-bent on destroying their sacred mountain. Please help the Dongria. We've watched your film - now watch ours. ${ }^{2}$

This act of symbolic protest by Survival International attracted the attention of the international media, which had the effect of highlighting the Niyamgiri Movement in the domestic Indian media as well. The importance of the international attention that the Niyamgiri Movement received was emphasized by its domestic supporters. In an interview the lawyer who represented the Dongaria Kondhs in the Indian Supreme Court stated: "what was the turning 
point...say... when Time Magazine did a story on the Dongaria Kondhs being the modern-day Avatar” (interview with Supreme Court lawyer, March 2013). It is important to note that this act of protest did not just highlight Niyamgiri's cultural value for the Dongaria Kondhs. It underscored that they were protecting their land from being destroyed, just as the $\mathrm{Na}$ ' $\mathrm{Vi}$ were depicted to do in Cameron's film.

ActionAid engaged with the Dongarias' religiosity by organizing mass worship ceremonies on top of the Niyamgiri Mountain, in which the Dongarias and members of other related Kondh groups participated. These ceremonies involved a ritual in which the Dongaria Kondhs would take a vow to protect Niyamgiri, and ceremonial discourses emphasized the Dongarias' rights to Niyamgiri as well as their responsibility in regard to its protection. The ceremonies are reported to have begun in 2009 and to occur in the month of February each year. Initially, these ceremonies were criticized by local activists who interpreted it as a politically motivated interference in the Dongarias' religiosity, and an invention of indigenous religious culture - later, they began to organize similar ceremonies, as a political assertion of the Dongarias' religious claims to Niyamgiri (Kraemer, Whiteman and Banerjee, 2013). It is important to note the prevalence of a cultural-historical discourse within mainstream Odiya society that constructs Adivasis, somewhat romantically, as forest kings (Rousseleau, 2009). This discourse is argued to have played a role in influencing local activists' readiness to foreground an emphasis on the losses that the Dongaria Kondhs would suffer if the Niyamgiri Mountain were to be mined (Borde, 2017).

Some of the local activist organizations involved in the Niyamgiri Movement were the Niyamgiri Suraksha Samiti, the Kalahandi Sachetan Nagrik Manch and the Samajwadi Jan Parishad. The reason for Indian activists' initial hesitation to engage with religious issues is 
perhaps the result of an attempt to maintain distance from the cultural-political strategies of Hindu nationalism - despite the fact (or perhaps because of) that scholars have identified a close affinity between the neo-traditionalist discourses which Indian environmentalists routinely deploy, and the cultural nationalism promoted by the Hindu Right in India (see Mawdsley, 2006; Williams and Mawdsley, 2006). To a large extent, the Dongaria Kondhs themselves did not have a strong voice in relation to the directions that the framing of the Niyamgiri Movement took. This however, is outside the scope of this study - some issues in this regard have been discussed elsewhere (see Borde, 2016; Kraemer, Whiteman and Banerjee, 2013).

ActionAid's initiative (which was later followed by that of local activists) of organizing mass worship ceremonies on top of the Niyamgiri Mountain at a site known as Hundaljali, which was situated $10 \mathrm{kms}$ away from Vedanta Resources’ proposed mining site, served the purpose of delimiting the Dongarias' religiosity to a specific and circumscribed site in danger of being disturbed by Vedanta Resources’ mining project. Such a spatially circumscribed religiosity had a better chance of claiming recognition and protection under Indian Law, and in fact, this was one of the tactics that ultimately led the entire Niyamgiri Movement to victory. In India, 'indigeneity’ is a contested identity and is without official recognition. Paradoxically, this identity enjoys special protection under Indian Law when interpreted as 'tribal' rather than indigenous (Karlsson, 2003). In the Indian context, the Indian Forest Rights Act which came into force in 2006 empowers forest-dwelling tribal peoples/Adivasis to "protect their cultural and natural heritage” (Forest Rights Act, 2006: Sec. 5). Since the Forest Rights Act recognized and protected cultural rights in relation to specific and bounded sites (Forest Rights Act, 2006: Sec. 6), the spatial circumscription of the Dongarias' eco-religiosity by ActionAid and local activist 
organizations was key. It is interesting that the Forest Right Act links forest rights-claims to duties, responsibilities and custodianship vis-à-vis forests and their biodiversity (Bose, 2010).

The Indian Constitution guarantees religious rights as a fundamental right, and as the Indian Forest Rights Act also demonstrates, the legal landscape in the country is receptive to articulations that are framed accordingly. However, in the context of the Niyamgiri Movement, Indian activists voiced that it was the movement's internationalization that helped them realize the strategic value of the frame of the Dongaria Kondhs' spiritual reverence for the Niyamgiri Mountain. When they saw the sympathetic reception of Survival International's symbolic protests abroad, and the political potential of ActionAid's representation of the Dongarias' religiosity, they pushed a similar emphasis to the forefront of the articulations of the entire movement (interview with national-level activist, March 2013), and situated it in the context of the international support that had been generated by the trans-national activists.

Therefore, it can be seen that the Niyamgiri Movement bridged the frame of environmental justice with the frame of indigenous rights. By emphasizing indigenous peoples’ roles in conserving biodiversity, it was able to attract international supporters by internalizing aspects of the globalized frame that valorizes indigeneity and demonstrating that the issue it championed had global as well as local importance. At the same time, the internationalized framing of the Niyamgiri Movement as a struggle to protect an indigenous sacred natural site was culturally relevant, as it allowed the movement to seek recourse to the legal resources offered by the Indian Forest Rights Act as well as the respect for religious rights enshrined in the Indian constitution. 
Frame internationalization and the Philippine-Palawan case: The ecological-indigenous frame:

The Philippine case study focuses on the struggle against nickel and gold mining in the southern part of the island Palawan. The anti-mining movement on Palawan started in the early 1990s when Japanese firms began to extract natural resources, and expanded substantially after the consolidation of the Mining Act in 1995, which made the unlimited extraction of natural resources by foreign parties possible. Activism intensified further when MacroAsia, a Philippine company, obtained a mining exploration permit that covered indigenous territories in this region in 2008. The anti-mining movement on Palawan frames its struggles primarily in environmental terms, but is also linked with indigenous issues, primarily the protection of ancestral land domains i.e. traditional community lands that are also relevant in terms of culture and spirituality (see Hirtz, 2003).

Many of the important actors involved in the anti-mining movement on Palawan are based in the island's capital, Puerto Princesa, and have an ecological/environmental outlook. The most important of these is ELAC (Environmental Legal Assistance Centre, Inc.). However, there are also several organizations focussed on indigenous peoples' rights that are also actively involved in the anti-mining movement in Palawan, such as NATRIPAL, working from Puerto Princesa, and ALDAW, working from the Southern municipality Brooke’s Point, and focused on claiming and protecting ancestral land domains. NATRIPAL's mission is also focussed on helping indigenous groups gain recognition for their land and has for example initiated projects that seek to strengthen the livelihoods of indigenous peoples. These organizations are organized under the umbrella organization called the PNNI. The PNNI can thus be considered the driving force of the anti-mining movement in Palawan. 
An important element of the anti-mining activism in Palawan was the 'Save Palawan Campaign', which began in 2011 and was focused on protecting Palawan's biodiversity and ecological value. It aimed at collecting ten million signatures for the banning of mining on Palawan. The man behind the campaign was Gery Ortega, who had been involved in anti-mining activism since 2004. Gery Ortega was a journalist, environmental activist and community leader. As a program director of the ABS-CBN Foundation Inc. (one of the country's biggest media companies), he was involved in organizing community tourism and as a journalist he worked for several Palawan radio stations. He started receiving death threats in 2009 and was killed in 2011 for his activism, which gave an enormous boost to the resistance towards mining and lifted the struggle up to the national and international scale through Gina López, a national celebrity who had befriended Gerry Ortega (fieldnotes, November 2011). The role of Gina Lopez is crucial here, as she is not only a celebrity, but is also known for her support for environmental causes through the ABS-CBN Foundation, of which she is the managing director. As of June 2016 she is the DENR (Department of Environmental and Natural Resources) secretary. From 2012 onwards she has been involved in an ecotourism community project as a way of offering an alternative livelihood to mining.

The groups involved in the anti-mining movement all have international allies, but how this plays itself out, takes different forms. ALDAW is an indigenous-focussed organization, works locally and is connected closely to the University of Kent and has counterparts that resist oil drilling in Peru. Their contact person at the University of Kent is active in co-organizing events, conducting and disseminating research and organizing field visits to the region for other organizations. Finally, ALDAW has established a network among Filipino migrants in Europe, and at times it has organized solidarity meetings to inform the Filipino community in Europe 
about the Palawan situation. NATRIPAL is funded by several international organizations of which USAID is one. Although these funding organizations might not directly pronounce themselves against mining, they do make the anti-mining movement possible by their support. LRC-KsK (Friends of the Earth), which operates mainly from the Philippine capital, is part of a worldwide network of Friends of the Earth offices and operates at the national Philippine scale. These international ties facilitate processes of frame bridging and the internalization of globalized frames, rather than result from it, as they provide the local and regional organizations with the necessary networks and capabilities to strategize and collect and produce information.

To lobby, litigate and mobilize collective action, organizations on Palawan engage mainly in the ecological framing of anti-mining struggles. In doing so, they make use of the global language of conservation, ecology and biodiversity that has found resonance in Philippine legislation and large-scale projects financed by the European Union and implemented by the WWF and the Department of Environment and Natural Resources (DENR) (Bryant 2002), among others. However, most environmentally-focussed organizations have in addition internalized aspects of the globalized frame of the valorization of indigeneity, by way of integrating an understanding of indigenous peoples as protectors of biodiversity and the environment in the ways that they frame their struggle. In the anti-mining struggle this has resulted in the bridging of the ecological framing of the movement with indigenous issues. At the same time, indigenous organizations also tend to emphasize the ecological framing of antimining struggles in the way they represent indigeneity. The added value of framing the antimining struggle as an environmental struggle, as we will show below, lies in the possibility that this creates to use environmental legislation in order to make claims against mining firms and the governing institutions that support them. Adding the 'indigenous element' simply amplifies the 
possible national and international legal resources that can be used in resistance towards extraction. Because there is greater political will to protect the environment than to protect indigenous peoples, the environmental argument is mostly foregrounded.

This results in what we call the ecological-indigenous frame in the anti-mining struggles on Palawan, which is built up of three interrelated elements. The first element is the island's rich biodiversity and ecological vulnerability. The Save Palawan website for example states in its banner "Palawan is stunningly beautiful" and "Palawan forests are being destroyed" (fieldnotes November 2011). As an activist lawyer emphasized in an interview, the situation of Palawan is ironic: whereas the island is described as the last ecological frontier, with many protected areas that fall under the special protection of environmental laws, there are also over 400 mining applications awaiting approval (interview with lawyer, November 2011). The second element is ecotourism as an alternative to mining (see Rasch 2013) as well as an alternative livelihood strategy to resolve poverty in indigenous territories. “Ecotourism, not mining on Palawan!”, Gina Lopez once published on the internet. As of 2012 Gina Lopez has indeed been involved in a (not uncontested) ecotourism project in Brooke’s Point.

The third building block is the 'indigenous element' and reflects the bridging of ecological and indigenous frames, or issues, into one single frame, the ecological-indigenous frame. This element becomes visible in the presentation of 'the forest' and biodiversity for the livelihoods of the people who live in the forest. ELAC for example approaches environmental issues from a perspective of human rights and social justice: people have the right to live in the environment that they depend on for their livelihoods (interviews ELAC November 2011). NATRIPAL and ALDAW also emphasize the importance of the forest for the livelihoods of indigenous peoples. Not only in terms of 'how to make a living', but also in a spiritual and 
cultural sense. Hence, it is argued that it is important to conserve nature, forests and biodiversity because this is important for the livelihoods of indigenous people. The way this ecologicalindigenous framing of mining struggles is constructed, is not a linear or chronological process, but it should rather be seen as being co-constructed by environmental and indigenous organizations that are working together against mining. By combining the ecological with the indigenous element, the anti-mining movement on Palawan expands the possibilities to resist extractive projects.

These different building blocks of the ecological-indigenous framing of the anti-mining struggles become very clear when we look at the strategies that different actors pursue in their activism against mining. The legal activist organization ELAC relies heavily on environmental laws for its litigation tactics. At the same time, ELAC and other NGOs, lawyers and activists are actively involved with indigenous peoples in Southern Palawan and have close ties to grassroots organizations that operate at the local scale through ALDAW. The founder of ELAC for example, remembers vividly how she, and other volunteering lawyers, would help indigenous peoples collect information about mining and would educate them about their rights when Japanese firms first started mineral-prospecting on indigenous lands at the beginning of the 1990s, thereby also enhancing the specific indigenous rights of indigenous peoples (interview, November 2011). The audience they aim to address in doing so is mainly regional and national; they aim at convincing the Philippine government to withdraw concessions issued to mining firms. To a lesser extent their audience is also international: the Save Palawan campaign speaks to an international audience via its internet campaign.

The ecological-indigenous framing of the anti-mining movement on Palawan resonates with the fact that indigenous peoples in the Philippines used to be protected under environmental 
law. Activists argue that this is the political language to speak: "in Manila they would rather spend money on the protection of an eagle than spend money on the lives of indigenous peoples” (interview with activist lawyer, November 2011). This point is also made by another lawyer, when she says that she actually considers it convenient that indigenous ancestral land domains are often located within the boundaries of protected areas, because these are protected by environmental law. As such, activist lawyers can stand up for indigenous peoples and their (cultural) indigenous rights within the UN-REDD (Reducing Emissions from Deforestation and Forest Degradation) framework, using its international language, because they are 'Reddable' (interview with activist lawyer, November 2011). Hence, whereas they recognise that they stand up for indigenous peoples and indigenous rights, they find it strategically relevant to do this within an ecological framework.

At the same time, another important law that is used in the anti-mining movement in Palawan and which reflects the bridging of ecological and indigenous elements into one frame, is the IPRA (Indigenous Peoples’ Rights Act, 1997). The IPRA lays down the rights of indigenous peoples and its issuance should be considered within the broader recognition of indigenous' rights globally, such as the recognition of indigenous rights in the ILO Convention 169 and the UN Convention on indigenous rights. The IPRA law makes it possible for indigenous peoples to claim their ancestral land domains. These ancestral land domains are understood to be rooted in land and nature, and to obtain an 'ancestral domain' certificate, the indigenous group in question has to prove its rootedness in the claimed territory, and not as a cultural group. Claiming these ancestral land claims is core to the work of the local organization ALDAW.

In terms of anti-mining activism it is important that the IPRA law also establishes the right to Free, Prior and Informed Consent (FPIC) of indigenous peoples, among other indigenous 
rights, which means that no programmes or projects can be implemented on indigenous lands without the free prior and informed consent of the indigenous peoples in question. Part of the work of local and regional activists involves organising independent FPICs and proving irregularities and fraud in the consultations organised by the government and by mining companies. Hence, legal resources, such as the IPRA law that are in line with the globalized valorization of indigeneity, and are aimed at the protection of indigenous peoples, are used to resist mining. The way that indigenous peoples are presented in the IPRA law, and in the process of acquiring an ancestral land certificate, also reflects the discursive connection that is made between nature and indigenous peoples. It is about proving how the concerned group relates to the territory and its natural resources. It thus sits well with other legal resources used in the antimining struggle that concern environmental protection.

To summarize, for resistance groups on Palawan the bridging of the environmental/biodiversity elements with the indigenous rights elements into one single ecological-indigenous frame allowed the local and provincial anti-mining movement to access a broader spectrum of legal resources and as such to address national and regional government institutions more effectively. The inclusion of a globalized indigenous agenda has facilitated access to the IPRA that allow for the protection of indigenous rights. While the IPRA is applicable at the domestic level, international-level policy instruments such as UN-REDD that support (indigenous) peoples' land and forest rights, are also used by the Palawan anti-mining movement. The FPIC of indigenous peoples which is central to the IPRA reflects a globalized trend of recognising indigenous rights: it is also stated in Article 10 of the United Nations Declaration on the Rights of Indigenous Peoples as well as the ILO Convention No. 169. Indigenous rights in relation to FPIC are also an important component of the UN-REDD 
programme. Internationalized framing of the movement, even when related to indigenous issues, resonates with the local concern for environmental conservation in the Philippines (Bryant, 2002). In doing so, it speaks to a national audience, that is more receptive to a discourse of biodiversity, than of the protection of indigenous peoples' rights.

\section{Comparative Discussion:}

The Niyamgiri Movement in India and the anti-mining movement in Palawan are examples of environmental movements against mining that aimed at protecting sites of cultural or sacred value for indigenous peoples. The emphasis on indigenous cultural rights with its inter-linkages with ecological conservation was a later addition to the Niyamgiri Movement, and it existed from the outset in the case of the anti-mining movement in Palawan. In the Niyamgiri Movement, the indigenous cultural rights frame was bridged with an environmental frame, after which the indigenous cultural rights frame began to dominate the framing of the movement. In the anti-mining movement on Palawan a similar process took place, where ecological and indigenous elements came to co-construct one frame as a way to understand and strategize the struggles against mining.

In the context of the Niyamgiri Movement, the inclusion of an indigenous religious/spiritual frame facilitated the internationalization of the movement, which was earlier framed as a local struggle for environmental justice. In the anti-mining movement in Palawan, the emphasis on environmental issues in tandem with indigenous rights, which came together also in the perceived importance of the environment for the livelihoods of indigenous peoples, allowed for the internationalization of the movement as well. 
For both the Indian and the Philippine social movements the internationalization of their framing was culturally resonant with local values and it can be argued that this process had the effect of making the movements even more relevant domestically. It is also important to consider how frame internationalization in these movements relates to issues of soft power - soft power is power that derives from internationally acknowledged legitimacy (see Gallarotti, 2011; Nye, 1990). It is significant that frame internationalization occurred in the Indian and Philippine social movements in those issue areas that are a source of soft power for each respective context spirituality in the Indian case and biodiversity in the Philippine case. It can be argued that frame internationalization increased the pressure on the Indian and Philippine governments to demonstrate a commitment to the norms and values for which each movement is internationally regarded.

\section{Conclusion:}

In this study we have brought together the concepts of internationalization and framing to stress the importance of framing in the internationalization of social protests, and to show how social movements aimed at a defence of place engage with globalization. Our study reveals how framing processes enabled these social movements against mining on indigenous lands in India and the Philippines to intensify their challenge to the Indian and Philippine governments respectively. We chose to compare movements in two nation-states rather than within one specific nation-state because this would facilitate a more nuanced understanding of the way domestic social movements experience internationalization. We have demonstrated that the context-specific framing of each social movement was not sacrificed in this process of frame internationalization. Furthermore, the national-level political outlook of each state did shape the 
way the globalized frame of the valorization of indigeneity was internalized by the two social movements and this is why (the nation-state context being important) we have termed the dynamic we have described in this study, frame internationalization, rather than frame globalization or frame glocalization. Dynamics whereby social movements shift or jump across scales and levels have been discussed by other scholars (see, Arts 2004) - and also with a specific relevance to framing (see Kurtz, 2003). However, instead of focusing upon scale shifts, our conceptualization of frame internationalization facilitates an understanding of framing processes by which social movements become multi-scalar (i.e., local, national and international). In the struggle against forms of globalized, neoliberal development such as mining (Graulau, 2008), a globalized frame that reflects a linkage between indigeneity and nature conservation appears to be one that social movements against mining in the Global South may be able to use with some success.

\section{Bibliography:}

- Arts, B. (2004). The Global-Local Nexus: NGOs and the Articulation of Scale. Tijdschrift voor Economische en Sociale Geografie. 95(5): 498-510.

- Benford, R. D. (1997). An Insider's Critique of the Social Movement Framing Perspective. Sociological Inquiry. 67(4): 409-430.

- Benford, R. D. and Snow, D. A. (2000). Framing Processes and Social Movements: An Overview and Assessment. Annual Review of Sociology. 26(1): 611-639.

- Borde, R. (2017) Differential Subalterns in the Niyamgiri Movement in India. Interventions: International Journal of Postcolonial Studies. 19(4): 566-582. 
- Borde, R. (2016) Legal interpretation of the sacred natural sites and cultural heritage of the Dongaria Kondhs in India. In: Verschuuren, B. and Furuta, N. (Eds.) Asian Sacred Natural Sites: Philosophy and practice in protected area conservation. Routledge: London. 107-117.

- Bose, I. (2010) How did the Indian Forest Rights Act, 2006, emerge? IPPG Discussion Papers. 39: 2010.

- Bryant, R. L. (2000). Politicized Moral Geographies: Debating Biodiversity Conservation and Ancestral Domain in the Philippines. Political Geography. 19(6): 673-705.

- Bryant, R. L. (2002). Non-governmental Organizations and Governmentality: 'Consuming’ Biodiversity and Indigenous People in the Philippines. Political Studies. 50(2): 268-292.

- Daly, H. E. (1999). Globalization versus internationalization - some implications. Ecological Economics. 31: 31-37.

- Della Porta, D. and Tarrow, S. (2005). Transnational Processes and Social Activism: An Introduction. In: D. Della Porta and S. Tarrow. (Eds.) Transnational Protest and Global Activism. Lanham: Rowman \& Littlefield Publishers Inc. 1-17.

- Dirlik, A. (1999). Place-Based Imagination: Globalism and the Politics of Place. Review. 22(2): 151-187.

- Djoghlaf, A. (2012) Foreword. In: G. Pungetti, G. Oviedo and D. Hooke. (Eds.) Sacred Species and Sites. Cambridge: Cambridge University Press. xvii-xix.

- Dove, M. R. (2006). Indigenous People and Environmental Politics. Annual Review of Anthropology. 35:191-208.

- Escobar, A. (2001). Culture sits in places: reflections on globalism and subaltern strategies of localization. Political Geography. 20: 139-174. 
- Garcia, F. J. (2013). Between Cosmopolis and Community: Globalization and the Emerging Basis for Global Justice. NYU Journal of International Law \& Politics. 46(1): 1-53.

- Goffman, E. (1974). Frame Analysis: An Essay on the Organization of Experience. Boston: Northeastern University Press.

- Graulau, J. (2008). 'Is mining good for development?’: the intellectual history of an unsettled question. Progress in Development Studies. 8(2): 129-162.

- Hames, R. (2007) The Ecologically Noble Savage Debate. Annual Review of Anthropology. 36: 177-190.

- Hirtz, F. (2003) It Takes Modern Means to be Traditional: On Recognizing Indigenous Cultural Communities in the Philippines. Development and Change. 34(5): 887-914.

- Johnston, H. (2002). Verification and Proof in Frame and Discourse Analysis. In: B. Klandermans and S. Staggenborg (Eds.) Methods of Social Movement Research. Minneapolis: University of Minnesota Press. 62-91.

- Karlsson, B. G. (2003). Anthropology and the 'Indigenous Slot': Claims to and Debates about Indigenous Peoples’ Status in India. Critique of Anthropology. 23(4): 403-423.

- Kapoor, I. (2004) Hyper-self-reflexive development? Spivak on representing the Third World 'Other’. Third World Quarterly. 25(4): 627-647.

- Kingsbury, B. (1998) “Indigenous Peoples” in International Law: A Constructivist Approach to the Asian Controversy. The American Journal of International Law. 92(3): 414-457.

- Koenig, T. (2006). Compounding mixed-methods problems in frame analysis through comparative research. Qualitative Research. 6(1): 61-76. 
- Kraemer, R., Whiteman, G. and Banerjee, B. (2013). Conflict and Astroturfing in Niyamgiri: The Importance of National Advocacy Networks in Anti-Corporate Social Movements. Organization Studies. 34(5-6): 823-852.

- Kumar, K. (2014). The sacred mountain: Confronting global capital at Niyamgiri. Geoforum. 54: 196-206.

- Kurtz, H. E. (2003). Scale frames and counter-scale frames: constructing the problem of environmental injustice. Political Geography. 22: 887-916.

- Levitt, P. and Merry, S. (2009) Vernacularization on the ground: local uses of global women's rights in Peru, China, India and the United States. Global Networks. 9(4): 441-461.

- Li, T. M. (2010). Indigeneity. Capitalism and the management of dispossession. Current Anthropology. 51(3): 385-414.

- $\quad$ Lindroth, M. and Sinevaara-Niskanen, H. (2013) At the Crossroads of Autonomy and Essentialism: Indigenous Peoples in International Environmental Politics. International Political Sociology. 7: 275-293.

- Mawdsley, E. (2006). Hindu nationalism, neo-traditionalism and environmental discourses in India. Geoforum. 37(3): 380-390.

- McAdam, D. Tarrow, S. and Tilly, C. (2001). Dynamics of Contention. Cambridge: Cambridge University Press.

- Merry, S. (2006) Transnational Human Rights and Local Activism: Mapping the Middle. American Anthropologist. 108(1): 38-51.

- Muehlebach, A. (2001). “Making Place” at the United Nations: Indigenous Cultural Politics at the U. N. Working Group on Indigenous Populations. Cultural Anthropology. 16(3): 415448. 
- Owen, J. R. and Kemp, D. (2013) Social license and mining: A critical perspective. Resources Policy. 38(1): 29-35.

- Pieck, S.K. (2006) Opportunities for transnational indigenous eco-politics: the changing landscape in the new millennium. Global Networks. 6(3): 309-329.

- Radcliffe, S. A. (2014) Plural Knowledges and Modernity: Social Difference and Geographical Explanations. In: K. Okamoto and Y. Ishikawa (Eds.) Traditional Wisdom and Modern Knowledge for the Earth's Future: Lectures Given at the Plenary Sessions of the International Geographical Union Kyoto Regional Conference, 2013. Springer: Tokyo. 79102.

- Rasch, E.D. (2013). 'Ecotourism, not mining in Palawan!': Territorial narratives on the last frontier (Palawan, the Philippines). In: B. Büscher \& V. Davidov. (Eds.) The EcotourismExtraction Nexus: Political economies and rural realities of (un)comfortable bedfellows. Abingdon: Routledge. 236-254.

- Reimerson, E. (2013) Between nature and culture: exploring space for indigenous agency in the Convention on Biological Diversity. Environmental Politics. 22(6): 992-1009.

- Rousseleau, R. (2009). The King’s Elder Brother: Forest King and ‘Political Imagination’ in Southern Orissa. Rivista di Studi Sudasiatici. 4 (1): 39-62.

- $\quad$ Ryan, G. W. and Russel B. H. (2003). Techniques to Identify Themes. Field Methods.15 (1): 85-109.

- Sahu, G. (2008) Mining in the Niyamgiri hills and Tribal Rights. Economic and Political Weekly. 15.

- Schroeder, R., Martin, K. St., Wilson, B and Sen, D. (2008) Third World Environmental Justice. Society \& Natural Resources. 21:7: 547-55. 
- Snow, D. A. and Benford, R. D. (1992). Master Frames and Cycles of Protest. In: A. D. Morris \& C. M. Mueller. (Eds.) Frontiers in Social Movement Theory. New haven. Yale University Press. 133-155.

- Snow, D. A., Rochford, E. B. Jr., Worden, S. K. and Benford, R. D. (1986). Frame Alignment Processes, Micromobilization, and Movement Participation. American Sociological Review. 51(4): 464-481.

- Sobrevila, C. (2008). The Role of Indigenous Peoples in Biodiversity Conservation: The Natural but Often Forgotten Partners. Washington: The World Bank.

- Steinberg, M. W. (1998). Tilting the Frame: Considerations on Collective Action Framing from a Discursive Turn. Theory and Society. 27(6): 845-872.

- Swyngedouw, E. (2004) Globalisation or 'glocalisation'? Networks, territories and rescaling. Cambridge Review of International Affairs. 17(1): 25-48.

- Tarrow, S. (2010a). Outsiders Inside and Insiders Outside: Linking Transnational and Domestic Public Action for Human Rights. Human Rights Review. 11(2): 171-182.

- Tarrow, S. (2010b). The Strategy of Paired Comparison: Toward a Theory of Practice. Comparative Political Studies. 43(2): 230-259.

- Temper, L. and Martinez-Alier, J. (2013). The God of the mountain and Godavarman: Net Present Value, indigenous territorial rights and sacredness in a bauxite mining conflict in India. Ecological Economics. 96: 79-87.

- $\quad$ The Scheduled Tribes and other Traditional Forest Dwellers (Recognition of Forest Rights) Act, 2006, Amendment Rule, 2012 \& Guidelines. Bhubaneshwar: Vasundhara.

- Thomson, A. (1998). Fifty Years On: An International Perspective on Oral History. The Journal of American History. 85(2): 581-595. 
- Vinayaraj, Y.T. (2016) Dalit Theology after Continental Philosophy. London: Palgrave Macmillan.

- Williams, G. and Mawdsley, E. (2006). Postcolonial Environmental Justice: Government and Governance in India. Geoforum. 37(5): 660-670.

\section{Notes:}

1) The term 'Adivasis' (which this study will employ), meaning 'original inhabitants', is used to denote what are generally argued to be India's indigenous peoples, though their indigenous status is not accepted by the Indian government (Karlsson, 2003).

2) Time, 13 February 2010 